Published as Katalin Orbán, "Trauma and Visuality: Art Spiegelman's Maus and In the Shadow of No Towers” Representations, Vol. 97, No. 1 (Winter 2007) , pp. 57-89.

Published by: University of California Press.

Article DOI: $\underline{10.1525 / \mathrm{rep} .2007 .97 .1 .57}$

\title{
Trauma and Visuality: Art Spiegelman's Maus and In the Shadow of No Towers
}

\author{
Katalin Orbán
}

Art Spiegelman's Maus $(1986,1991)$ and In the Shadow of No Towers (2005) are parallel books, devoted to historical crisis as family history -- the former to the Holocaust, narrated through the experiences of the author's family, the latter to the attack on the World Trade Center, narrated, once again, through the experiences of the author's family. There are some important differences, however, and I will focus on their relationship through a particular one: the role of images in the two books. While both have a tortured, ambivalent relationship to their own visuality in representing historical and private trauma, they differ in their motivations for this struggle, due to a difference in subject matter, and they use images differently to resolve their problems. "The historic crimes of this century are in no small part due to extreme abstraction, the nearly pathological furor of thought accompanied by a complete lack of imagination," says novelist Imre Kertész (2001) in a lecture on the role of intellectuals in ideological totalitarianism. When Kertész contrasts the fascinating attractiveness of a closed world of thought with the artist's "agonizing proximity" to the surrounding world's experiential reality, he imagines this experiential closeness primarily as looking at the world. Yet, in this by now familiar critique of thinking totality, the "eyeing" of the world-presented as the alternative to the theoretical intellectual who is only vexed by experience and must at all cost be protected from freedom--cannot be so comfortably aligned with one side of the equation. While vision is the exemplary, representative observation of the world in modernity, it presupposes distance and is itself a powerful regime of abstraction, a rival form of world-making easily allied with the furor of thought Kertész holds responsible in his comment. This warrants a more thoroughly ambivalent relationship to vision and the image as both in the service of and an obstacle to a difficult proximity to one's subject, and such a relationship is central to both of Spiegelman's books.

In the representation of the Holocaust, it is visuality's deliberate departure from the document that creates the problem; in other words, the documentary photograph and film are the visual reference points relative to which the "prohibitions” on visual invention ostensibly apply and relative to which Maus negotiates its use of the image. In the representation of the attack on the World Trade Center, what poses a threat for the text is visuality's unintended absorption into the lightness of the infinitely repeated and repeatable 
televisual documentary image, into the CNN-image-as-document. So in Maus, the work's main concern is how not to overwrite another visual archive of its subject; in Towers, how not to be overwritten by it. In their efforts to achieve these elusive goals, both works cultivate a kind of blindness in their readers, or rather two quite distinct kinds of blindness. The first notion of blindness is an ability to see inwardly, without the eyes, canceling the visible image - this notion reverses the idea of blindness as a disability, since it offers a deeper, immediate understanding unhindered by the eye. Therefore, it is the visual apparatus itself that is the more profound disability in this idea of blindness as true sight. This notion of blindness is more compatible with a dual view of the body as healthy or pathological, and its reversal lends itself to a more metaphorical view of blindness. The other notion of blindness is associated with an ability to see haptically, through touch. Unlike the total annulment of the image associated with an immediacy of understanding, this idea of blindness is associated with proximity, the closeness that permits contact and from which the coherent image breaks up into the details of a surface. This notion of blindness has more affinity with the concept of the body on a continuum of diverse imperfections, its different faculties intermixing and aiding each other. (Nicholas Mirzoeff [1995] traces this in some detail in his book Bodyscape.) In both books, materiality and embodiment are important for understanding the contested role of the image-Maus, despite any suggestion of an unsighted contemplation of the Holocaust, commits itself to the visual in the images of its embodied creatures, and Towers rethinks the graphic artist's relationship to immaterial images in a book that is a touchable, layered, heavy material object.

These two high points in Spiegelman's career so far are separated by a good fifteen years. After its publication, Maus quickly became a canonized, influential work of secondgeneration Holocaust narrative: a standard reference point and an item on course syllabi. A Pulitzer Prize Special Award in 1992, continued critical and popular success, numerous translations, exhibitions, a multimedia CD-ROM (1994)—Spiegelman barely survived this transition from the relative anonymity of the alternative commix subculture to his sudden success and fame as a graphic artist (a success he worries about in the second volume of Maus, for good reason). Indeed, over the next decade and a half Spiegelman was many things - the creator of memorable, at times scandalous New Yorker covers, a commix expert, a writer of introductions, the promoter and illustrator of little-known, unusual works by others, the editor of commix collections - he was everything but the writer of his own next book after Maus. In this respect, the rubble of the World Trade Center was a historical gift that fell into his lap—almost literally, since he lives in Lower Manhattan—a trauma finally bis own, in which historical catastrophe is both personal and family history, as it was in Maus. If the transmission and reception of the testimonial narrative is a heavy burden in Maus, the listener's difficult gift to receive and to give, this new, personally experienced shock also seems both arduous and liberating for the artist who can at long last almost move beyond the vicarious narrative of the Holocaust.

Spiegelman himself links the two events, the two stories, and the two books. This link refers the reader of the commix to perception outside the realm of the word and image. In one of the panels in Towers, Spiegelman draws himself in the style familiar from Maus and says: „I remember my father trying to describe what the smoke in Auschwitz smelled like. / 
... The closest he got was telling me it was ... 'indescribable'... / /... That's exactly what the air in lower Manhattan smelled like after Sept. 11.!” (3). It is no accident that the two stories connect in this both visually and textually unrepresentable smell: the "indescribable" smell draws attention to traumatic memory as both close and out of reach, far from the father's failing powers of description, but close to somatic experience, the sense least accessible to intentional recall or blocking. The indescribable smell indicates why traumatic memory does not count as a memory proper and that it exceeds the powers of description offered in either book.

\section{Empty Screens}

In Maus the use of the image against itself relies primarily on the anthropomorphic, hybrid creatures, which are often read as a means of visual masking - an amplification of the mask motif to a more general metaphor (Fig. 12). A noticeable trend in Maus criticism has employed this idea of the mask to relieve the book of its visual burden. Yet, as I will show later, these creatures are also key obstacles to this suppression of visuality; their bodies are the most significant gesture in Maus inviting the reader to get deeper into, even get lost in the visuality of the text.

\section{IMAGE OMITTED FOR REASONS OF COPYRIGHT}

FIGURE 1: ART SPIEGELMAN, MAUS: A SURVIVOR'S TALE, VOL. 1, MY FATHER

BLEEDS HISTORY, 1973, 136.

The images of Maus are crucial, because they position Maus relative to ostensible limits on Holocaust representations, though their originally transgressive impact is increasingly difficult to see now due to the work's great success and rapid canonization. Within the debates concerning the propriety of non-documentary response to the Holocaust, the resistance to visual representation has been particularly strong. These visual representations, like other artworks, pose the more general question how appropriate the component of pleasure in creativity and art appreciation is to the Holocaust, and how well the imagination can cope with this particular set of historical events and their historical, philosophical and moral significance. As visual representations, they also encroach on what became the predominant mode of documentary representation in the $20^{\text {th }}$ century. With the advent of photography and film, which gave documentation media that could combine iconic similarity with the indexical trace (a chemical aftereffect of the documented object) the image has become far more closely associated with authentic documentary truth than the word, the verbal record. The visual prohibitions guarding this truth apply to Maus even more acutely, because roughly half of its plot takes place in the "concentrationary universe" itself (as distinct from a range of spaces and events beyond the concentration camps which are also commonly included in the referent of the word Holocaust, such as restriction of movement, deportations, massacres). This ties the question of authenticity more closely to the visual, just as the genre of the commix ties the question of pleasure and consumption to the visual too; this is because it is the primarily the image that marks the commix as the supposedly low, mass market product for the "semiliterate." 
The estranging effect of the animal characters, which constantly alerts one to the artificiality of visual representation, relieves the work's images of some of this burden. Of course, the stylized minimalism of the comics does not offer the full illusion of realism in the first place, but the animals destroy this illusion more radically. We can see the reconstructed workshop in the camp, where in the hope of survival Vladek Spiegelman pretends to know something about fixing shoes, and we also see a mouse working in a striped prisoner's uniform. This anti-realist use of the image keeps confronting readers with what they see and what they don't. The improbable images draw attention not only to their own limitations, but also to the object of loss itself, that which they are unable to show. In this sense, the images do not represent their referent, but rather prompt viewers to mobilize their imagination, using the book actively as a starting point: to remember, to think, and to see the best they can.

This use of the image, then, demands a kind of inspired image-blindness of the reader, an idea actually confirmed by Spiegelman's remark which compares the animal heads to the empty look of the classic American commix character, Little Orphan Annie, and compares both to "a white screen the reader can project on" (Spiegelman et al. 1994, 46). In this comic, which Harold Gray began to draw in 1924, Annie's eyes are always empty and white, and never look anywhere (while she solves problems very capably during the Depression). This infinitely empty or infinitely full gaze, seeing simultaneously everything and nothing, is an important, recurring motif of Western visual art and culture: blindness as true sight (Mirzoeff 1995, 37 - 57). This is how the reader of Maus can (and must) see the Holocaust. Furthermore, the empty gaze-and the animal head that serves the same purpose in Spiegelman's work-evokes not only a connection, the connection of blindness and understanding. It also evokes a disconnection: that dissociation of sight and comprehension that is central to trauma and a recurring element in the Holocaust survivors' accounts. In his “Caught by Images," Ernst van Alphen follows Pierre Janet's distinction between traumatic and narrative memory and calls such traumatic memories visual imprints. These imprints, he argues, are images that were never comprehended and never turned into memories; they were quasi-photographically recorded and return with a "visual and sensorial directness" but do not lead to understanding, thus contradicting "the privileged epistemological status of the observation of the visual world" (van Alphen 2003, 98).

The visual mask, as explained by Spiegelman and his critics, replicates this idea of blindness. The image is merely a prompt that indicates a beyond which is either directly accessible in some pure immediacy of comprehension or remains forever isolated and unassimilated. Even though such readings acknowledge the painstaking visual work that goes into creating such prompts, their emphasis is on pointing, on what does not appear. On this reading, the images such as those of the Selektion scene (and its recounting and reenactment) overtly, even ostentatiously, display themselves as representations and thereby cease to function as such (2:58). This is what Spiegelman and numerous critics refer to as a directness or immediacy. "[] t would be counterfeit to try to pretend that the drawings are representations of something that's actually happening," says Spiegelman. "I don't know what a German looked like who was in a specific small town doing a specific thing. My notions are born of a few score of photographs and a couple of movies. ... To use these 
ciphers, the cats and mice, is actually a way to allow you past the cipher at the people who are experiencing it. So it's really a much more direct way of dealing with the material" (Spiegelman and Mouly 1981, 105 - 106). The two seemingly contradictory ideas of immediacy and inaccessibility merge in this commentary by Spiegelman: I have no idea, but it's a direct way of dealing with the material. This direct way supposedly short-circuits experience with experience (me, experiencing the text, short-circuited with the "people who are experiencing it"). It bypasses the representation, which somehow erases itself in the process. This is the directly, immediately accessible "dark side of the image" where we are apparently catapulted by the obvious limitations of the visual in comics. When comparing Spiegelman's earlier experiments with his final visual style developed for Maus, one critic calls the minimalism of the "masklike quality" of the drawings "a more direct and immediate" style (Witek 1989, 112). This is essentially a temptation to make the image bear the burden of representation and therefore to make it disappear. Spiegelman's term cipher, meaning both code and zero, sums up in a single word this wish for the visual code to erase itself.

This invitation to blindness is confirmed by a curious phenomenon in the critical reception and in the authorial explication: the inclination to make images disappear by treating them as masks is often combined with a surprising willingness to accept words as transparent-without having to be made transparent. In this case, the visual stands in for what does not appear, while words are allowed to stand by their ostensible promise of presence and authenticity. It is not at all self-evident why this expansion of the mask motif to a governing metaphor for representation should not apply to words and images equally, because words are representations too. The interpretation of the animal coding of the characters (and, indeed, the commix genre) as a mask relies on a tradition of depth models where the signifier stands for a latent, more essential, more authentic substance. While this notion of authenticity is itself dubious, it entails no necessary hierarchy between words and images.

It is all the more curious that the textual elements of the book, its captions and speech bubbles are not described as masklike, because the speech conventions of the comics are highly artificial and draw attention to signs as signs. Commix usually present words in speech balloons, which hang in the visual space of the panels, obstructing our view, although they contain objects that do not exist in the represented space. If images are masks and words are not (an idea consistent with blindness as true sight), authenticity can be tied more closely to the survivor's testimonial speech than to the mixed media of the listener's account of it. When Michael Rothberg $(1994,671)$ calls Vladek's text speech, one could take it as a reference to the direct speech in the speech bubbles, but when Marianne Hirsch (1992-93, 12) refers to Vladek's testimony as aural, the words of Maus are conclusively identified with the father's spoken word -- as if Vladek's unmediated authentic speech existed in this work separately from its multiple recordings and transcriptions. Though this is qualified at some point as an "impression," the "unmediated authenticity" of this virtual aurality is validated in the analysis overall: Hirsch says, for example, that "it seems that in the aural realm, Spiegelman seeks absolute unmediated authenticity, while in the visual, he chooses multiple mediations." So Spiegelman gives us the tape recorder (unmediated authenticity in the word), 
but not the visual equivalent in the image: the camera. This distinction, however, seems to underestimate the importance of the fact that the tape recorder is a little drawing. Both of these critics have made the same observations in less stark forms in later versions of these arguments, so it might seem unfair to select the more extreme formulations of this statement, but what I want to emphasize is how a drawn tape recorder and stylized speech in speech bubbles are made to stand in for speech itself, for an aural presence opposed to the visual mask. This is what is at stake in strategically suppressing the image.

More recently, this opposition of the image and the authentic word has been returning even in texts very sensitive to the role of transmission and representation in what we call historical facts, such as "The Holocaust as Vicarious Past" by James E. Young, who doesn't share Witek's or Spiegelman's point about the direct, immediate effect of the commix. In fact, Young highlights the indirection of the medium and the triangulation of meaning between words, images, and the reader's eye.

The result is a continuous narrative rife with the discontinuities of its reception and production, the absolutely authentic voice of Spiegelman's father counterpoised to the fabular images of cartoon animals. ... Meaning is not negated altogether, but the meaning created in the father's telling is immediately challenged in the son's reception and visualization of it (Young 2003, 30).

The way I see it, Maus hardly suggests that the pure presence of the witness's word could be transparently communicated (were it not for the interference of visual mediation). In this "writing," Vladek's words are written--they are written by Art, which does not mean they are fictional. In fact, Maus obsesses over the problem of writing as constructed and opaque, where no inscription or transcription is completely innocent or transparent. Actually, in other parts of his essay, Young seems more than willing to concede this about Maus, which makes it all the more significant that this opposition appears even in his text. The CD-ROM material (like the audio samples included in MAUS exhibitions) actually confirms that the idea of the authentic word in Maus is technically, concretely inaccurate. The testimonial word in the book, as Nancy K. Miller observed as early as 1992, is a distorted, stylized representation of Vladek's actual recorded speech. The CD-ROM, which delivers transcripts and audio samples of the recorded testimonial speech and far more photos than the book, also demonstrates that the mythic site of absolute, unmediated authenticity is never reached in either word or image, not even when we have real recorded testimony and lots of photographs. My main point, however, is not that the authentic word is not there in Maus, but rather how it is often wished to be there as a counterpoint to the masklike image.

Andreas Huyssen's "Of Mice and Mimesis" too, which has every premise that would have to prevent it from taking this position, ends up extolling reading over looking. After positing that Maus undercuts the dichotomy between visual representation and the ban on images, Huyssen's argument quickly slides into the now familiar move pitting the inauthentic image against the word's power to authenticate. The only variation is that, for once, the image does not vanish; it turns out to be a script. In the complex relationship of "Bilderverbot and mimesis, [the image] approaches writing," and the images are, in fact, a script to be read (Huyssen 2003, 131). Huyssen finds a "good witness" for this in Spiegelman 
and quotes the authorial explanations that Maus is a "comic book driven by the word" and that Spiegelman "wanted [the drawings] to be there, but the story operates somewhere else. $[\ldots]$ By not focusing you too hard on these people you're forced back into your role as a reader rather than a looker."

Yet, Maus is a visually engaging work, which ultimately resists this approach and resists its own invitation to blindness, because it cannot avoid the problem of the body, not even within its self-imposed visual limitations. Several hundred pages of detailed narrative familiarize one with the convention of the animal coding, letting the visually improbable animal characters coexist with the psychologically realistic and familiar people (this, of course, only applies to the mice, the animal characters whose narrative role allows us to get to know them better) and promote the reader's "suspension of disbelief." The increasing familiarity of the convention thins out the visual allegory and weakens the insistence on that something else which presumably we should be seeing instead of mice, cats, and pigs. Incidentally, this familiarity also presents--indirectly, of course--the familiarizing and naturalizing of the Holocaust narrative. However, this familiarity alone would merely moderate the anti-visual impulse to bypass the image and would not anchor Maus in the visual as positively and affirmatively as the body does. It is the represented body that most powerfully undermines the notion of visual masking and blindness as true sight in Maus and ties the book and its reader to the image. While the stylized animal heads are where the metaphor of masking is most obviously in play, the bodies complicate this within the visual. No matter how we interpret the animal codes of Maus, the head is the distinctive feature. Mouse heads, cat heads, pig heads, dog heads, and so on. The hybrid body is "unnecessary," and it should become invisible and irrelevant. It does not.

The insistence of this body is difficult to decode in terms of masking, because it incorporates the difference to which it refers; it marks an excess in representation rather than sending us elsewhere. It is not an image of not seeing that refers one to a traumatic event which even its witnesses are unable to see. Instead, it is an image that captures the excess, the too much of trauma in the visually represented body (Figure 13).

The role of the hybrid, as I see it, is to disturb the whole concept of the visual mask. If the "false appearance" of the hybrid body is corrected and the characters are restored to a congruous body either as animals or as humans, the work is relieved of a source of the very unease it creates visually around the dehumanizing, dehumanized human animal. It is relieved of some of the dissonance that is always part of the reading pleasure in Maus.

\section{IMAGE OMIT'TED FOR REASONS OF COPYRIGHT}

\section{FIGURE 2: DETAIL FROM SPIEGELMAN, MAUS, 2:26.}

This view of the hybrid body as true would probably not convince the editor at The New York Times, who insisted that Maus ought to be classified as fiction and allegedly "suggested ringing Spiegelman's doorbell to see if a giant mouse would respond" (Introduction). Of course, the hybrid bodies are not "true" in this sense. Not surprisingly, the more a critical reading treats the animal as a fabular mask ("a premise to be absorbed and then put out of mind" [Witek 1989, 112]), the more it tends to ignore the hybrid body, as something that makes no sense. One critic says, "We are not really confronted by animals playing people's roles but by humans who wear animal masks" (Brown 1988, 105). Either 
way, the human and the animal remain separate for the critic. Yet, these repeatedly shown bodies visually exceed conventions of the animal fable, as the body assumed under the human clothes becomes visible whenever characters are represented naked--and they often are. They are in normal, domestic images of casual undress (getting up, lying in bed), and they are as prisoners and corpses in the camp.

Granted, this might never come up in another comic book where characters are always fully clothed or are drawn fully as stylized animals. Therefore, someone might object that this is simply a matter of practical necessity; it just so happens that, unlike in other comic books using animals, the characters reveal their bodies, so Spiegelman has to show it somehow, whereas in other cases we just do not find out. But the point is that it doesn't just so happen: the necessity of presentation goes to the heart of this comic book being about the Holocaust. According to Joseph Witek's history of the graphic novel, one of the "distinguishing marks" of the animal commix tradition is a "curious indifference to the animal nature of the characters," and he quotes Carl Barks, who "always conceived of Donald as a human being who happened to be shaped like a duck" (Witek 1989, 110, 109, 112). This is not so simple when the question What is not buman? is a fundamental question raised by the subject of the work, the Holocaust, and when this question constantly appears in the somewhat grotesque image of the shared human-animal body. This naked body is eminently an image to be seen rather than to be seen through. It does not say what is human and what is not human; it just keeps asking this question, very quietly but constantly. Potential answers range from precise biological description to moral norms, and between the precision of racial theory and the norms of human dignity lies the entire history of the Holocaust and the split self-image of Western culture. So Spiegelman does not really have the option of not dealing with the body. And because he deals with the material body in the way he does, he reclaims his images from the blindness the book otherwise cultivates in its reader.

Once we approach the images of the book not as mementos or mnemonic codes, but as visible images, their meaning will depend more on their arrangement, textures, and details and will allow for a more dynamic relationship between visual and textual meaning in interpretation. For example, a page consisting of eight panels unites the family members at a dinner in 1940 and Vladek listing them as he rides his stationary bike in the book's present. This listing, of course, mirrors that other inventory that was taken between the two temporal stages and led to the death of all these family members, so Vladek's list reverses itself, because all those who were present are gone, and the two who happened to be absent from the dinner, visiting the New York World Fair, survived. (1:74). The composition unites the act of narration with the narrated scene and we can see both that Vladek is riding his stationary bike from Sosnowiec and Auschwitz all the time, in every panel, and that he will never quite arrive in America (how could he, with such a slow-moving means of transportation). Treating images this way works against blindness and draws the reader into that visual world of meaning where historical reality merges with something that only exists between the covers of the book, a place the book calls Mauschwitz.

Resisting a blind reading of the image and attempting to see the image in its materiality instead has its own problems, however. The temptation to see into the material 
and possibly lose oneself in the details can call forth a care that cannot justify itself except as an obsession. Visual details become key evidence the reader should trust excessively. (Let me add that obsession can, of course, be a legitimate approach in interpreting an event of historical trauma such as the Holocaust.) I will illustrate this with a very visually oriented reading of smoke in Maus, one that also takes us back to Spiegelman's link between his two books: the indescribable smell of the smoke and the air in Auschwitz and in Lower Manhattan.

The image of the crematorium chimney with smoke coming out of it, which occurs in many panels of Maus, is one of the emblematic images in Holocaust iconography, which is indeed a strong invitation for indexical reading: a reference to something absent that caused the sign to come about. The smoke, though iconic (it looks like smoke), represents an indexical sign: the trace of lost human lives. (This is how Lanzmann's Shoah, the most influential filmic argument for blindness as true sight and for the primacy of the testimonial word, uses it in images of smoke in the present-day "spectral landscape" of a forest or the train arriving in Treblinka. ${ }^{1}$ ) The smoke is an index of the fire that burns the bodies-a signifier which is a causal effect and trace of what it signifies, like a footprint. If this aspect of the image becomes overwhelming in interpretation, its visual meaning dissolves in a heightened sense of loss, the loss of the people killed in Auschwitz, the trace referring us back to something unshown. Resisting such a view of the image, Michael G. Levine (2003) pays attention to small visual details_-such as the identification of Auschwitz smoke with the smoke of Art's cigarette in a panel—to develop an extensive and illuminating analysis of how Maus figures the second-generation artist's relation to trauma as a compulsive-rhythmic activity that seeks to bury the dead yet also brings Auschwitz to life time and time again. When one treats the image this way, it leads further and further into the representational space of Maus. This connection between breathing as a life-sustaining physiological process, the inhalation and exhalation of smoking with its compulsion, pleasure, and toxic damage, and the destruction of life in the bodies burned in the crematoria visually creates a meaning that serves as a clue to read further images and words in Maus.

In Maus, the smoke of the crematoria is always drawn as a densely hatched black shape, and that black smoke clearly stays in the panel below. How should one read this "whitening" of the smoke? As processing or cleansing or a measure of the inadequacy of memory or understanding? What seems important to me is that such questions send us back into the representational space of the work. If we want to answer them, we need to draw on representation rather than move past it. And this is where we get into trouble in a new way. In the same analysis, Levine notes: "If one draws a line connecting the top of the chimney on the upper right to the lid of the cigarette pack on the lower left, it passes directly through the glowing tip of Art's 'Cremo Light."' True, if one draws a line like this, and especially if one draws this line the right way (I didn’t quite succeed in doing so), it will turn into visual

\footnotetext{
${ }^{1}$ Lanzmann uses images of the burning brush in the Ben Shemen forest (Israel), a location intended to remind the interviewed witnesses of the Ponari forest outside Vilna (Lithuania), where Jews were massacred, their bodies later dug up to be burned. For a detailed analysis of spectral evidence and trauma, see Ulrich Baer (2002).
} 
evidence. It is not that there aren't sufficient visual clues to support the tenuous connections through which representation itself is made to give up its meaning. There are always more clues. The problem is that it is so hard to decide at what point the reader begins to resemble the person who is convinced she can receive the radio signals from Mars through her tooth filling. I am saying this as someone who finds Levine's essay an especially illuminating and nearly always persuasive example of this approach. In fact, he is the first to acknowledge that this reading requires him to "follow the faintest of leads." Thus, the material infinity of the visual text is just as treacherous as the infinity of the transcendent loss that lurks behind the mask. But it makes a big difference which of them tempts a reader more: it is the difference between seeing or seeing through the images of the work. Maus plays its cards both ways. It invites the impulse to read its images as if blindly, as self-erasing prompts, but it doesn't push us towards an ideal of non-optical, inward seeing as thoroughly or as conclusively as some critics argue, and it never gives in to the corresponding impulse to elevate the word in the way some of its critics and, occasionally, its author do. These critical impulses draw attention to something important: seeing such images of the Holocaust, and of historical trauma more generally, primarily as not the testimonial word and not the documentary image can effectively blind us to them. This blinding can be considered a great thing, if one thinks that ultimately we should always return to the testimonial word and the documentary image. However, not seeing them is potentially a great loss, partly because these images embody our changing, developing relationship to the traumatic past. The cultivation of this kind of inspired image blindness is also becoming historically obsolete, because at this point it makes more sense, not only practically, but even philosophically, to think about the Holocaust in terms of the relationship to processed and overprocessed images and texts, including commercial film and television and forms in which documents such as testimonial accounts are organized, contextualized and made accessible. This, in fact, is the central visual dilemma in Spiegelman's later book, In the Shadow of No Towers.

\section{Texture and Materiality}

In Towers, the issue is not whether the visual representation of the subject can be appropriate and authentic at all, but rather what can be a visual alternative to the infinitely light and infinitely repeatable mediatized images, imitating overly familiar film scenes and intimating presence as a convention of genre. The uneasy relationship of this book to the eerie irreality of the televisual sublime and to tele-suffering (to adopt a term Geoffrey Hartman [2001, 119] takes from Luc Boltanski [1999]) is central to its struggle with its own visuality. The book is a pictorial journal of the days, weeks, and months after September 11, 2001 in ten single-page chapters - how the Spiegelmans ran to get their daughter from the school at the foot of the towers, how someone on Canal Street was painting the burning towers, how Spiegelman quarreled with a homeless "Crazy Lady" who blamed the Jews for the attack, and so on (6). In this visual and verbal commix chronicle, the sharpest distinction Spiegelman draws is not between seeing and not seeing. What he emphasizes is not whether someone saw the plane hitting the tower with his own eyes or only saw the face of another 
who did see it; as it happens that someone who misses it is Spiegelman himself, narrated in a third-person account of Our Hero's actions. The Spiegelmans, who are walking north, miss the image, but not the moment, at which they hear the sound of impact (ROARRRRRRRR!!) and see the face of the woman who says "Gott in Himmel!" (2). The sharper distinction is between witnessing and watching television, where witness is not limited to eyewitness.

Spiegelman methodically works into his record of the events a number of things he did not see: in chapter 6 , this is the main role of the recurring image of the tower, variations of which appear on every page. According to the caption, Spiegelman "keeps falling through the holes in his head"; in the image, he is falling from the tower. „He is haunted now by the images he didn't witness... images of people tumbling to the streets below... especially one man (according to a neighbor) who executed a graceful Olympic dive as his last living act" (6). He does not fabricate this visual record (instead of the man, the panel shows him tumbling rather ungracefully); instead, he incorporates the verbal account as a witnessing of a "last living act," despite it being hearsay. This generosity towards non-televisual experience is defined politically as Spiegelman's new-found "rooted cosmopolitanism"--both rooted in the local community of the neighborhood and in accidental, improvised connections in material space rather than in the symbolic national community represented by the flag. (A similar combination of spontaneity, materiality, and an emphasis on the local, communal context characterized the improvised memorials in Lower Manhattan after September 11.) This idea of suddenly finding oneself rooted in a place, an idea somewhat accidental and spontaneous in nature, is very different from the necessity and permanence that underwrites nationalist discourses of being rooted. In fact, even the classic comic book characters that feature in the book are part of the neighborhood, having been disinterred by the blast from neighboring Park Row where the great newspaper wars had been fought between Hearst and Pulitzer a few blocks from Ground Zero.

In the making of the book, this focus on the local corresponds to a partiality to detail, which means that Spiegelman's account will never be finished (let alone repeatable). In his ironic synopsis of Chapter 2, he notes that ,last week the artist began describing his September $11^{\text {th }}$ morning and only got up to about 9:15... Considering that it takes him at least a month to complete each page, he should've started this 'weekly' series in September 1999 to get it all told by Judgment Day" (3). Whatever he does produce is created with emphatically artisanal and ridiculously obsolete methods that cannot keep stride with the "events." Most importantly, the book emphasizes its relationship to electronic, televisual images by foregrounding them in its material (as subject matter) and playing against them in its own material (paper). Firstly, the use of classic comics characters and the large format of the book, which imitates the Sunday comic supplement, tie the narrative to the history of American comics, to print popular culture before television. Spiegelman integrates the comic supplement in the book in two ways: by incorporating its styles and characters into his own drawings and by adding a Comic Supplement of six full-page panels to his own ten pages at the end of the book - a very significant gesture, given the proportions. Rudolph Dirks's antiauthoritarian Katzenjammer Kids appear as twins wearing the World Trade Center towers as hats. Spiegelman appears as the uncultured nouveau riche father in George McManus's 
Bringing up Father, fighting a news war with his wife who cannot sleep because Spiegelman watches CNN all night and who wakes him up with the blaring radio in the morning. We also encounter Spiegelman's familiar mouse alter ego in the role of the famous Ignatz mouse in George Herriman's Krayy Kat. ${ }^{2}$ Making the most of correspondences between current events and the violence, hate, anxiety, surreal New York dreamscapes, and "little terrorist" kids in the early comics, this historicization bypasses the television-aided image revolution of the second half of the $20^{\text {th }}$ century and returns to the great newspaper wars of its early decades.

The struggle against the weightless image is signaled even more clearly by all the emphasis on the book as a material object. It is not only large in format, but is also made out of the thick cardboard often used for children's first books (typically picture books); just as those are toys as much as books, this is an object as much as it is something to read and look at. The base material necessary for the appearance of the image and text does not disappear as if auxiliary. The book is, of course, a mechanically reproduced mass product (as in the case of Maus, Spiegelman, consciously avoided the genre of the unique or limited edition artist's book, opting for easy reproducibility), but its visual strategy runs counter to this, if not in actual fact, then at least in illusion. The use of disparate tonal scales and surface textures results in more than just a fractured, fragmented visual surface, intimating the difficulty of "getting the picture" after a historical and personal shock; it alludes specifically to collage, creating the illusion of layering, of a depth and materiality of different types of material pasted onto each other. This material depth signals a non-transparent, though archeologically penetrable depth (an illusion effectively backed up, so to speak, by the heavy, thick cardboard) that sets these images apart from the technology of electronic images.

This emphasis on texture and materiality, the image as material rather than visual object, is not entirely illusory. The inside pages of the ten commix chapters merely look as if they were textured and play with the idea of the collage, but the framing pages and covers actually have these tactile layers. On the first and last pages, the words of the title, and two circles containing the incomplete image of the glowing tower and the scampering Katzenjammer Kids as the towers, all in color superimposed on a faded grayscale newspaper background are, in fact, layers of foil pasted on the image of the hundred-year old paper. The palimpsest of current news clippings and the New York Times cover from September 11, 1901 (conveniently covering the arrest of “Anarchist Queen” Emma Goldman and the assassination attempt on President McKinley) merely imitates the palimpsest and fades its papers artificially, but these sticker-like layers of foil are actually distinct to the touch. Their separation in color and glossiness invites touch, and they confirm the emphasis on materiality and texture in a tactile rather than conceptual way. On the front and back cover too, the glossy black towers, the classic cartoon characters falling from the sky, and the lettering of the title are all superimposed on the matte black background (recalling Spiegelman's famous black-on-black New Yorker cover that showed the towers nearly imperceptibly). The silhouettes of the free-falling, tumbling commix characters on the entire

2 The Katzenjammer Kids by Rudolph Dirks were published from 1897; Bringing Up Father by George McManus and Krazy Kat by George Herriman were published from 1913. 
large back cover and part of the inside covers is where this strategy of tactile visuality, the touchable image is most pronounced and where the book most powerfully extends an invitation to blindness quite different from that proposed in Maus. This is not a seeing beyond and seeing inwardly, but rather seeing differently, through touch, and this is where the analogy with children's oversize picture books takes on another meaning: Towers is about the desire and challenge to see differently, re-learning to see despite one's over-exhausted eyes (or, as Spiegelman says, our "jaded $21^{\text {st }}$ century eyeballs"). Belying the bulkiness of the book, its surface is vulnerable; the scratches inevitably left by use become part of the image, the disappearing of the image through wear and tear reappearing as the material object's visible history (Figure 14).

This "seeing differently" amounts to blindness only if one equates seeing with optical visuality predicated on an ideal of abstract, illusionistic space, an equation underwritten by centuries of dominant traditions in Western art history. Art historian Aloïs Riegl used the term tactile or haptic visuality in an early $20^{\text {th }}$-century analysis of the parallel rise of figurative space and decreasing physical tactility in visual and decorative art. In his historical narrative, Riegl distinguishes the near view from the distant view: withdrawal from the range of tactile contact allows for the distant view which "leads us to see a flat plane where in reality a modeled, three-dimensional space exists." This is due to sensory deception, the shortcomings of the "human visual apparatus." Restoring the near view works against the optical illusion and returns one from illusionistic space to "memories of tactile experience" and to the impression of an "objective surface." Riegl calls this surface- the one perceived when the eye is close to an object-objective in order to emphasize its difference from the illusionistic plane perceived from a distance (Riegl 2004, 188 - 189).

IMAGE OMITTED FOR REASONS OF COPYRIGHT

FIGURE 3: DETAIL FROM ART SPIEGELMAN, IN THE SHADOW OF NO TOWERS, 2004, BACK COVER.

(Riegl's assumption that the near view of the material is physically real rather than illusionistic is, of course, untenable in an absolute sense of ontological privilege - the view of what he calls "objective surface" is no unmediated access to matter itself, as is abundantly clear in an era of ever more enhanced microscopic, thermal and other imaging of matter.) Although the surface of Spiegelman's book is not textured in this "objective" sense except for a few important pages, the interest in the material and tactile is reinforced in the book's overall visual strategy, in its weight, in the need to turn the object from time to time, and so on.

This retreat from the image to mere materiality-where the image is not primarily image but rather a tangible object, a thing-could be a nostalgic attitude, a search for some original Eden before CNN and before digitization, as perhaps suggested by the evocation of commix history as well. However, Spiegelman's book is not written in the spirit of such a naïve analog utopia. It invokes a post-digital, post-electronic materiality rather than a preelectronic one. Towers acknowledges the key role of the mediatized image-never denying its power, even while subjecting it to bitter sarcasm-and looks for small, local bearings in an entirely non-edenic world. Spiegelman's book often shows the TV screen and the act of watching television in its images and frequently mentions them in its text; in fact, the whole 
book opens with a three-panel sequence depicting a nuclear family slumped in front of a television (Figure 15).

Except for the numbers marking the dates Sept. 10 and Sept. 11 on the calendar, this sequence is completely non-textual. As our perspective is from behind the TV set, we can only see the viewers' faces, but not the image on the screen.

\section{IMAGE OMITTED FOR REASONS OF COPYRIGHT \\ FIGURE 4: DETAIL FROM SPIEGELMAN, IN THE SHADOW OF NO TOWERS, 1.}

In the second panel, the father, mother, and child jump up in fright and everyone's hair, including the cat's, is frizzled and stands up on end, as if they had just had an electric shock. By the third and last panel, they have returned to their slumped pose, sinking into the couch, and one couldn't even tell anything happened if it weren't for their frizzled hair and the calendar replaced by an apparently timeless and permanent patriotic flag. This sequence could easily be taken for a simple illustration of the passivity of watching television, but its representation of the effect of the televisual experience on viewers is more complicated. In its radical simplicity, the last panel combines the horrific, the comic, and the ironic- the ironically clichéd American family with a permanent bad hair day, where hair is both the comically exaggerated signal of emotion (a convention of the genre) and the unprocessed incorporation of trauma. Since Spiegelman shows this somatic imprint of trauma in a family who are watching television, the sequence weakens the sharp distinction maintained elsewhere between physical presence and electronically mediated relationships. Consequently, these images do not question the role and effect of the televisual image in contemporary American society, even though they are created from the perspective of material, non-television reality, externally, as it were.

Perhaps the single most contradictory element of the entire book with respect to the lightness and repetition of the image and its relationship to trauma is the way Spiegelman draws the towers themselves. Taking advantage of the oversize picture book format, the imitation of the Sunday comics supplement of newspapers, he often draws them large, framing the page, using the full 20 inches of the longer side of the opened book. This pushes the image from similarity towards repetition, as if the image had to be big if it is to depict a tall tower (unlike on television, where everything looks small, "not much bigger than, say, Dan Rather's head," says Spiegelman, while logos "look enormous" [1]). This oversize and at times fragmented image shows the towers at a particular moment of lightness that Spiegelman tries to reproduce visually in an admittedly manic, obsessive way: the moment when the towers are poised on the borderline of material being and abstract nothingness, glowing and almost floating translucently before collapsing into themselves-an image Spiegelman did see and found "awesome." This invokes the notion of the sublime even as it undermines its totality through the obsessive repetition of the traumatic image. This recurring image (27 panels in the ten pages) is the key instance of the dissolution of the coherent image into texture, into a play of color that does not make sense beyond itself. (Therefore, its translucence is only superficially like the Tribute in Light memorial, which has a more immediately symbolic and stable meaning.) It is a "near view" of the towers, 
where the effort to understand brings the eye close to the object and disperses meaningful figurative space into a surface that "transfixes" the viewer

This repeated image is also the visual counterpart of the title of the book: In the Shadow of No Towers. As in the case of "Mauschwitz," it denotes a concrete place that does and does not exist, a site from which and about which the book is written. This site-in the shadow of no towers - is marked by an absence dense enough to cast a shadow. Does the precarious balance of the glowing towers fall in the direction of transcendent loss and nonexistence (no towers)? Or in the direction of tangible, material being (one that can cast a shadow)? In either case, we would find ourselves outside the realm of the overused, repeated televisual image. Spiegelman's whole book is suffused with the desire to have it that way and with the knowledge that it cannot be so. The final page of the commix rebuilds the two towers out of the smaller panels, letting them shrink and fade in the final three. In the gap between the two towers, we can see flames below and an airplane at the moment of contact at the top. The simultaneity of the image makes it indeterminate if the time of this composition is ordinary life where time passes and life goes on, a time where the towers stand once again, or a time where time keeps stopping and the airplane keeps hitting the tower. In this composition, the meaning of "again" hovers just like the small drawing of the plane before the moment of the impact. What is this "again"? Reliving or replay? The repetition of trauma or that of the "teevee" image? (The role of the latter is invoked not only by the image of the moment of contact, but also by the panels recounting the anecdote of Spiegelman-as-Hapless-Hooligan being disqualified from an NBC interview due to insufficient patriotism.) Instead of resolving this visual dilemma, the text rather accentuates it through the puzzling final words that may be offered in high seriousness or melancholy irony: Happy Anniversary.

This enigmatic conclusion, which is the most unified and visually homogeneous tableau of all ten, also underscores the investment of Towers in the image to the point of resisting narrative - a difference from Maus with some important implications. Although this monument to "when time stopped" incorporates many small stories into its individual pages and these individual pages all contribute to an overarching though lacunar narrative of the event and its aftermath, narrative is predominantly contained within the individual tableaus; the story threatens to explode this container-the big frame of the page within which the dynamic, controlled chaos of the panels plays out--yet we are invited to face the tableau, to linger rather than move on. Unlike in Maus, which unfolds its allegorical premise into an ever more complex narrative flow (a method analogous to the narrative extension of the figure in parables [Orbán 2005, 56-59]), Towers is a page-non-turner, where each page encloses and locks in narrative for extended perusal. These tapestries extend the time of viewing rather than the time of narrative progress.

This arrested narration fits the glowing towers and the disinterred comic characters that are like the ghostly, undead characters often found in post-apocalyptic fiction, exemplifying a liminal state and incomplete mourning. The great, textually and visually earned strength of this narrative is the affectionate and intimate relationship that Spiegelman's book builds with them-with the towers he had never even liked and with the commix characters he had always loved. Like Spiegelman himself, this commix is both more 
rooted and more cosmopolitan than the War on Terror and is itself a compelling argument against the Bush administration's "hijack[ing]" of the events. More compelling, in fact, than the directly political rhetoric in the book, which is comparatively flat. This is perhaps the risk Spiegelman takes by recording his response so immediately, so close to the event. The "near view," while meaningful in the visual strategy of the book, is ultimately less satisfying as a more general lack of perspective. This lack of distance is also explained by the different narrative situation and "ownership" of trauma in the two books. Without the benefit of the built-in mediation of the testimonial relationship he had in Maus, Spiegelman adopts the comic characters to serve a similar mediating purpose in Towers, but, of course, receiving an ultimately unknowable real human being's story is radically different from projecting one's own into Hapless Hooligan. The meandering, conversational narrative structure of Maus, with its distractions and derailings, models a relationship of genuine curiosity that proceeds from a position of not quite knowing--not quite knowing what one finds even in one's own experience and not quite knowing what one is doing. Towers abandons this weakness for the sake of a univocal political message in its tableaus, which ultimately restricts what its spectacles of disarray can tell us, whether we stand near or far, with open or closed eyes.

\section{References}

Baer, Ulrich. 2002. Spectral Evidence: The Photography of Trauma. Cambridge, MA: MIT Press. Boltanski, Luc. 1999. Distant Suffering: Morality, Media and Politics. Translated by Graham Burchell. Cambridge: Cambridge University Press.

Brown, Joshua. 1988. "Of Mice and Memory." Oral History Review 16 (1): 91 - 109.

Hartman, Geoffrey. 2001. "Tele-Suffering and Testimony in the Dot Com Era." In Visual Culture and the Holocaust, edited by Barbie Zelizer. New Brunswick: Rutgers University Press.

Hirsch, Marianne. 1992-93. "Family Pictures: Maus, Mourning, and Post-Memory," Discourse $15(2): 3-29$.

Huyssen, Andreas. 2003. "Of Mice and Mimesis: reading Spiegelman with Adorno." in Present Pasts: Urban Palimpsests and the Politics of Memory. Stanford: Stanford University Press.

Kertész Imre. 2001. A számürött nyelv [The Exiled Language]. Budapest: Magvető.

Levine, Michael G. 2003. "Necessary Stains: Art Spiegelman's Maus and the Bleeding of History." In Considering Maus: approaches to Art Spiegelman's "Survivor's tale" of the Holocaust, edited by Deborah R. Geis, 63 - 104. Tuscaloosa: University of Alabama Press.

Miller, Nancy K. 1992. "Cartoons of the Self: Portrait of the Artist as a Young Murderer." $M / E / A / N / I / / N / G$ 12: $43-54$.

Mirzoeff, Nicholas. 1995. "The Canon of Blindness." in Bodyscape: Art, Modernity and the Ideal Figure. New York: Routledge.

Orbán Katalin. 2005. Ethical Diversions: The Post-Holocaust Narratives of Pynchon, Abish, DeLillo, and Spiegelman. New York: Routledge.

Riegl, Aloïs. 2004. Historical Grammar of the Visual Arts. Translated by Jacqueline E. Jung. New York: Zone Books.

Rothberg, Michael. 1994. “We Were Talking Jewish': Art Spiegelman's Maus as 'Holocaust' Production." Contemporary Literature 35 (4): 661 - 687.

Spiegelman, Art et al. 1994. "Mightier Than the Sorehead." Nation 258 (2): 45 - 54. 
Spiegelman, Art, and Françoise Mouly. 1981. "Jewish Mice, Bubblegum Cards, Comics Art, and Raw Possibilities.” Interview by J. Cavalieri. Comics Journal 65: 105 - 106.

Spiegelman, Art. 1986. Maus: A Survivor's Tale. I. My Father Bleeds History. New York: Pantheon.

Spiegelman, Art. 1991. Maus: A Survivor's Tale. II. And Here My Troubles Began. New York: Pantheon.

Spiegelman, Art. 1994. The Complete Maus, CD-ROM. Produced by Elizabeth Scarborough.Voyager.

Spiegelman, Art. 2005. In the Shadow of No Towers. New York: Pantheon.

van Alphen, Ernst. 2003. "Caught by Images: Visual Imprints in Holocaust Testimonies." In Image and Remembrance: Representation and the Holocaust, edited by S. Hornstein and F. Jacobowitz. Bloomington: Indiana University Press.

Witek, Joseph. 1989. Comic Books as History: The Narratice Art of Jack Jackson, Art Spiegelman, and Harvey Pekar. Jackson: University Press of Mississippi.

Young, James E. 2003. "The Holocaust as Vicarious Past: Art Spiegelman's Maus and the Afterimages of History." In Witnessing the Disaster: Essays on Representation and the Holocaust, edited by Michael Bernard-Donals and Richard Glejzer. Madison: University of Wisconsin Press. 